\title{
Business Model Innovation The Role of Leadership
}

\author{
Foss, Nicolai J.; Stieglitz, Nils
}

Document Version

Final published version

Publication date:

2014

\section{License \\ CC BY-NC-ND}

Citation for published version (APA):

Foss, N. J., \& Stieglitz, N. (2014). Business Model Innovation: The Role of Leadership. Institut for Strategic Management and Globalization. SMG Working Paper No. 2/2014

Link to publication in CBS Research Portal

\section{General rights}

Copyright and moral rights for the publications made accessible in the public portal are retained by the authors and/or other copyright owners and it is a condition of accessing publications that users recognise and abide by the legal requirements associated with these rights.

\section{Take down policy}

If you believe that this document breaches copyright please contact us (research.lib@cbs.dk) providing details, and we will remove access to the work immediately and investigate your claim. 
BUSINESS MODEL INNOVATION: THE ROLE OF LEADERSHIP

Nicolai J. Foss

And

Nils Stieglitz

SMG WP 2/2014

10. February, 2014 
SMG Working Paper No. 2/2014

February, 2014

ISBN: 978-87-91815-93-5

Department of Strategic Management and Globalization Copenhagen Business School

Kilen, Kilevej 14A

2000 Frederiksberg

Denmark

www.cbs.dk/smg 


\title{
BUSINESS MODEL INNOVATION: THE ROLE OF LEADERSHIP
}

\author{
Nicolai Foss \\ Department of Strategic Management and Globalization \\ Copenhagen Business School \\ Kilevej 14, second floor \\ 2000 Frederiksberg, Denmark \\ njf.smg@cbs.dk \\ and \\ Department of Strategy and Management \\ Norwegian School of Economics \\ Breiviksveien 40 \\ N-5045 Bergen, Norway \\ Nils Stieglitz \\ Frankfurt School of Finance and Management \\ Sonnemannstr. 9-11 \\ 603214 Frankfurt am Main, Germany \\ n.stieglitz@fs.de
}

Forthcoming in Nicolai J Foss and Tina Saebi, eds. Business Model Innovation: The

Organisational Dimension. Oxford: Oxford University Press.

\section{February, 2014}

Keywords: Business models, complementarities, leadership.

JEL Code: D21, L23, M10 


\title{
BUSINESS MODEL INNOVATION: THE ROLE OF LEADERSHIP
}

\author{
Abstract \\ We draw on the complementarity literature in economics and management research \\ to dimensionalize business models innovations. Specifically, such innovation can be \\ dimensionalized in terms of the depth and the breadth of the changes to the \\ company's business model that they imply. In turn, different business model \\ innovations are associated with different management challenges and require \\ different leadership interventions to become successful.
}




\section{INTRODUCTION}

In spite of the massive attention in the practitioner and research literature over the last decade to business models and the innovation thereof (cf. Massa \& Tucci, 2013; Zott, Amit \& Massi, 2013), little or no research so far has dealt with the leadership aspects of business model innovation ("BMI") in a systematic manner. And yet, business model innovation can be a massive organizational change process that places very heavy demands on top-management and potentially strains the organization. Moreover, business model innovations are far from homogenous. Some may involve relatively minor connected changes in, for example, the customer segments that are addressed and the revenue model in a business unit. Other BMIs may be massive corporate-wide processes that involve basically all employees and all processes and activities. It seems reasonable to argue that different BMIs therefore pose different leadership requirements.

However, we know of no analysis that systematically links BMI, appropriately dimensionalized, to an understanding of the different competences of leadership and organizational design that are required to cope with the challenges represented by different kinds of BMIs. This is not to say that organizational and leadership challenges associated with business models and BMI have been neglected; in fact, this is far from being the case (e.g.,Chesbrough \& Rosenbloom, 2002; Margretta, 2002; Casadesus-Masanell \& Ricart, 2010; Chesbrough, 2007, 2010; Demil \& Lecoq, 2010; Doz \& Kosenen, 2010; Teece, 2010; Zott \& Amit, 2010; Amit \& Zott, 2012). However, existing research does not offer a contingency perspective. A key reason is that the unit of analysis is not clearly characterized. Specifically, existing research does not adequately represent the heterogeneity of BMI, and therefore does not dimensionalize BMI. In turn, the different leadership challenges that different kinds of BMI give rise to are not identified. 
Accordingly, in this chapter we take some preliminary steps towards a developing a theory of the leadership requirements of BMI, given a theoretically grounded dimensionalization of BMI. The theory is fundamentally a contingency theory and leaves out many important process aspects. Our reasoning starts from noting the inherently systemic character of business models. Indeed, as argued elsewhere in this volume (e.g., Foss and Saebi, chapter 1), the main contribution that the business model literature has brought to macro-management theory may well in retrospect turn out to be an emphasis on the need for integration of and coherence among strategic choices related to value proposition, segments, value appropriation models, and value chain organization. It is well known from the literature on coordination in complex systems that system elements may stand in different relations of specificity and complementarity to each other (Lachmann, 1956; Milgrom \& Roberts, 1990; Williamson, 1996; Levinthal, 1997). The need for leadership and a planned approach to the allocation over responsibilities, roles, and tasks - that is, organizational design-, derive from such interdependencies. We argue that a key dimension along which business models (and hence the innovation thereof) may differ is exactly in terms of the strength of the interdependencies, or, as we shall say, "complementarities," between their constituent components.

The purpose of this chapter is to unfold this overall theme. By placing complementarity" centrally in our thinking about BMI, we add to the literature by 1) developing a taxonomy of BMI that is based on a dimensionalization of BMIs in terms of complementarity; 2) identifying limits/constraints to successful BMI; and 3) highlighting the role of the top management interventions in terms of making BMIs successful.

\section{BUSINESS MODELS AND COMPLEMENTARITIES}

\section{Business Models in the Space of Strategic Management Theory}


Although science can make progress even in the presence of considerable conceptual ambiguity, there is little doubt that scientific advances are assisted by the presence of construct clarity (Suddaby, 2010), particularly clarity of the key constructs that organize and differentiate research efforts, streams and programs. Distinct research streams thrive by organizing research around core constructs that are clearly delineated from core constructs in other, neighboring research streams. The concept of a business model was coined several decades ago (Bellman \& Clark, 1957; Jones, 1960), and sustained, cumulative academic work that is explicitly organized around the business model construct has been going on for at least a decade-and-a-half (e.g., Chesbrough \& Rosenbloom, 2002). ${ }^{1}$ And yet, no single, clear, unifying definition of the construct that is also clearly delineated from related constructs has been advanced. What we have instead is a plethora of definitions (see also Foss \& Saebi, chapter 1), many of which bear a distinct resemblance to existing constructs in strategic management. For this reason, many of the proponents of the business model construct have often been at pains to differentiate it from more established strategic management constructs (e.g., Casadesus-Masanell \& Ricart, 2011). Sometimes business models are seen as subordinate and sometimes as superordinate to business strategy. Our position is that the business model concept has drawn attention to a fundamental perspective in strategy that arguably was present at the inception of strategy thinking but was forgotten as academic specialization came to characterize strategic management. The perspective is outlined in the following quotation (Rumelt, Schendel \& Teece, 1991: 5):

...firms have choices to make if they are to survive. Those that are strategic include: the selection of goals; the choice of products and services to offer; the design and configuration of ... competitive strategy; the choice of an appropriate level of scope and

\footnotetext{
${ }^{1}$ We do not here pursue the theme of whether earlier research (e.g., Teece, 1986) in actuality dealt with business models, even though it did not use the term.
} 
diversity; and the design of organization structure, administrative systems and policies

used to define and coordinate work ... It is the integration (or reinforcing pattern)

among these choices that makes a set a strategy.

This definition of strategy accords well with, for example, Zott, Amit and Massa (2011:

1037) argument that a business model is a "system level concept" that contains a "systemic and holistic understanding of how an organization orchestrates its system of activities for value creation" (Massa \& Tucci, 2013: 9). What makes it "systemic" is exactly the notion that the choices can be reinforcing, as suggested by Rumelt et al. (1991).

\section{Defining Business Models}

Teece (2010: 172) provides a neat definition of a business model as the “ $\ldots$ architecture that the company has chosen for its value creation and appropriation mechanisms." The key word in this definition is "architecture." We define an architecture as the set of relations among elements in a system (Simon, 1969), where these relations can be characterized in such terms as directionality (i.e., are relations sequentially or reciprocally dependent?), strength, and content (notably, information content). The architecture can in turn be characterized in terms of complexity.

In the context of a business model, extant literature suggests that the relevant elements are clusters of activities that can be grouped under the headings of the company's overall value proposition (What?), the market segments it addresses with this value proposition (Who?), its mechanisms of value appropriation (How much?), the structure of the value chain required to create and distribute the offering, the complementary resources needed to support the firm's position in this chain, and the processes and internal organization of the firm that support the other elements in the business model (How?). Thus, a business model is a system made up of the 
interdependent activities that allows the company to address the What, Who, How, and How Much questions.

While much discussion of business models mentions interdependencies (notably Amit \& Zott, 2012), there has been a strong tendency in the more applied literature to emphasize one or two elements of a business model; for example, such as "freemium" business models which call attention to only the value proposition and the revenue model or "cutting out the middleman" models that only highlight value chain aspects. While this is so is an interesting issue from the point of view of managerial cognition. However, the point here is that such discussions typically neglect the interdependencies between activities underlying a business model—and accordingly neglect the distinct organizational and leadership challenges present in systems with interdependencies. Although interdependencies are fundamentally choice variables (Milgrom \& Roberts, 1990) and there may be business models with weak interdependencies between activities, they certainly cannot always be neglected. The case of the BMI of Danish toy producer, Lego, may illustrate this (Foss, Schultz, Pedersen \& Pyndt, 2012).

\section{Business Model Innovation in Lego}

Lego, headquartered in Billund, Denmark, is currently the world's second largest toy producer with 10,000+ employees worldwide, and 2012 sales of approximately 4,5 billion USD and profits of about a billion USD. Though not a big company internationally it has no doubt exhibited a high performance over the last decade growing from a position as the seventh largest toy producer to the second place in a stagnant industry. However, in 2004 the company was on the verge of bankruptcy, arguably as a result of an ambitious diversification strategy. Partly prompted by the expiration of the basic Lego brick patent in 1983, the company had diversified into theme parks, merchandise, and products that essentially had little to do with the emphasis on 
construction and creative play that had been core values since the inception of the company. This had been accompanied by a strategy of pursuing a high degree of vertical integration.

Massive losses and decline in sales towards the end of 2004 led to the dismissal of the $\mathrm{CEO}$ and the appointment of a new CEO, Jørgen Vig Knudstorp who with a PhD in business administration and serving as the manager of Lego's internal strategic planning unit was a peripheral insider with strong analytical capabilities. Over the coming years he essentially innovated the Lego business model in four key dimensions. Specifically, Knudstorp trimmed the product offering and the number of inputs entering into Lego products; restructured the supply chain in terms of engaging in substantial outsourcing and offshoring; made the company's boundaries vis-á-vis customers and users substantially more permeable by creating user communities and engaging in joint new product development efforts with major customers; and stepping up the digitalization content of both operations and products.

With respect to the trimming of the product portfolio and the use of component inputs, Lego phased out production most non-construction Lego toys (many licensing agreements have been kept, however), sold of major assets, notably the Lego theme parks, and reduced the number of sourced product components from 12,700 to currently approximately 6,000 . Knudstorp's moves here were explicitly influenced by organizational economics, as he reasoned that reducing products and inputs would strongly reduce managerial complexity and bring down internal transaction costs. Similarly, the many changes in Lego's supply chain away from the highly vertically integrated model was explicitly inspired by the belief that hierarchy is the option of last resort (Williamson, 1996) and that firms in general do well by relying on the high powered incentives of the market. Thus, much actual production activity was outsourced to Flextronics, a Fortune 500 company and one of the world's leading supply chain service firms. 
Many of the outsourced activities (in Hungary and the Czech Republic) had already been offshored from Denmark to save costs. Lego kept the production of more advanced products (such as Lego Technic and Bionicle) in Billund close to headquarters. Difficulties of maintaining plastic quality later led Lego to insource some of those activities that had been outsourced to Flextronics.

In terms of reaching out to users and customers, Lego engaged in a series of activities, such as Lego Factory which encouraged children to build their own designs using Lego Digital Designer Software) (the activity was closed 2012, though the software remains in the public domain; close cooperation on the new product development with Wal-Mart and Toys "R" Us; and the establishment of Lego Certified Professionals, thirteen adults "super users" worldwide who are allowed to use the Lego concept in, for example, the production of lamps or customized solutions for select customers (e.g., building company headquarters in Lego bricks).

The above initiatives were supported by a consistent digitalization process, not only internally and with respect to sourcing partners, but also with respect to customers and users.

The above changes, which played out between 2004 and 2008, involved a set of interrelated changes in business model component. In terms of the earlier simple distinction between the "what," "who", "how" and "how much" components of a business model, Lego's BMI involved changes in all four components. Thus, in the "What" dimension, the change amounted to a change back to construction as the core, in harmony with the key company value "creative play." This change was consistent with the increased emphasis on digitalization to the extent that this may be seen as being about leveraging the creativity dimension in virtual space. These changes included changes in the Who dimension. Of course, those segments that demand traditional non-construction toys were eliminated from the Lego customer portfolio, while Lego 
strengthened its outreach to sophisticated, adult users. In terms of the How dimension, Lego engaged in substantial outsourcing and offshoring, as explained above, and also made numerous changes in terms of strengthening incentives and changing the allocation of decision rights inside the company. In particular, the company's purchasing functions was decentralized to support the strong reduction of the number of sourced components that had exploded because engineers held decision rights to initiate component purchase on their own. The increased emphasis on permeable downstream company boundaries, that is, working closely with sophisticated buyers and users, was also a change in the How dimension as this organizational allowed the company to execute an open innovation strategy. Finally, in the How Much dimension Lego's performance was strongly improved by the trimming of the product and component portfolios, offshoring and outsourcing, and a continuous emphasis on cost-cutting and lean.

As indicated, the various changes in the Lego business model fed on each other. A simple way to represent this is captured in Figure 1 which juxtaposes the four business model elements in Lego and how its process of BMI from in the 2004 to 2008 period involved interconnected changes in these elements. ${ }^{2}$

\section{------- Insert Figure 1 Here --------}

And yet, the fact that the changes were implemented sequentially rather than simultaneously suggests that the changes did not possess maximum interconnectedness (in which case they would have to be implemented exactly simultaneously). However, once implemented the changes in the Lego business model constituted an interlocking system because each element of the model feeds on the other ones. The technical term for this systemic property is "complementarity" and the individual business model elements are "complements." As we

\footnotetext{
${ }^{2}$ The figure can be refined in a number of ways, for example, by detailing the activities underlying the various business model elements.
} 
argue next, he complementarity framework provides a convenient, choice-theoretic approach to thinking about BMI in terms of definition, performance consequences and difficulties of implementing it.

\section{Complementarities and Business Model Innovation}

A basic assumption in the complementarity framework is that if changes in $\mathrm{n}$ activities can be made separately, changes can also be made simultaneously (Brynjolfsson \& Milgrom, 2013: 15). A broad definition then states that complementarity obtains if the profits from doing the activities jointly is higher than the sum of the profits from doing the activities in isolation. If the changes involve design decisions involving fixing the levels of a set of variables (say, $\mathrm{x}$ and $\mathrm{y}$ ), complementarity obtains when choosing a higher level of $\mathrm{x}$ raises the returns of choosing a higher level of y and vice versa (more precise definitions, based on lattice algebra, may be found in Milgrom \& Roberts, 1990; Brynjolfsson \& Milgrom, 2013). The connection to Figure 1 is easily seen (cf. also Brynjolfsson, Renshaw, \& Van Alstyne, 1997).

From the point of a strategist and organizational designer complementarities represent both opportunities and constraints. Because of the fundamental synergistic property of complementarities they represent opportunities for additional value creation. In fact, if all activities are not completely flexible in the short run (which they virtually never are) opportunities tend to be larger in the long run than in the short run in systems with complementarities. The reason is that some decisions will have to be fixed in the short run but can be made flexible in the long run (as in the textbook economics analysis of the firm's production decision). For this reason systems of complementarities will typically exhibit momentum in the sense that doing $\mathrm{x}$ at time $\mathrm{t}_{0}$ will make it more attractive to do $\mathrm{y}$ at $\mathrm{t}_{1}$ and perhaps z at t 2 . Lego's process of BMI from 2004 to 2008 seems to exhibit such a dynamic: The 
initial reduction of the product offering allowed for a concentration of fewer suppliers and realizing scale economies in purchasing. Concentrating purchasing in turn eased the more widespread use of outsourcing. Outsourcing and offshoring drove massive cost savings that helped support the company's increased emphasis on digitalization which in turn facilitated a stronger engagement with users and customers. Given this momentum it is not surprising that Lego seized its largest profits after its BMI was completed.

Although realizing complementarities would seem to be a key goal of the strategic organization designer, systems with complementarities may be complex and have multiple local equilibria that can usually be ranked on some performance criterion (notably, productivity or profitability). Usually the global optimum is by no means given to the decision maker, but can only be approximated through a process of more or less deliberate search (Levinthal 1997; Gavetti \& Levinthal, 2000; Stieglitz \& Heine, 2007). Such search processes may reveal the existence of hidden complementarities that represent further opportunities for increasing profits.. Conversely, search may reveal the existence of "anti-complementarities" or organizational substitutes (Siggelkow, 2002). Thus, Brynjolfsson, Renshaw and Alstyne (1997) document an instance of business process reengineering where new flexible manufacturing equipment was installed but used for the purpose of long, uninterrupted product runs by a supervisor and a team that relied on decades-old heuristics developed for traditional manufacturing practices (Brynjolfsson \& Milgrom, 2013: 27).

\section{Search, Learning and Business Model Innovation}

In management research, the NK model, originally developed in evolutionary biology, has developed into a workhorse model to capture complex tasks such as the design of business models (Kauffman, 1993; Levinthal, 1997). In the model, parameter K captures interactions 
between design elements and shapes the ruggedness of search space. The more pervasive the interactions (the higher the K), the more local optima exist, and the more difficult and uncertain is the identification and development of high performing business model. How an organization structures and manages its search process becomes critical for ultimate performance. At the same time, the NK model also reveals that complementarities, while challenging BMI, also serve as an effective barrier to imitation (Rivkin, 2000; Lenox et al. 2010) that isolates the innovator from imitative competition (Rumelt, 1984) (if not from other kinds of competition). The tighter the fit among business model elements, the harder it becomes for competitors to imitate the basis for competitive advantages, and the more likely is it that imitation of only parts of the business model deteriorates performance (Rivkin, 2000; Ryall, 2009). Thus, complementarities are a bane to successful BMI, but a blessing for protecting its rewards.

Viewed from the complementarity perspective, BMI is very much a process of search, learning, experimentation, usually with uncertain performance prospects. Recall that it took Lego four years to develop and execute its new business model, and many of its new elements were not in place when the top management began the re-design. Given that a new business model is not planned ex ante, but usually emerges in an extended design process (Mintzberg \& Waters, 1985; Gavetti \& Rivkin, 2007), the emphasis shifts toward how to structure and manage the process of innovating the business model. Leadership and organizational design may facilitate, channel, or even impede the search for a new business model. However, while prior research has focused on the benefits and the outcomes of BMI, the leadership and organizational design challenges BMI are strongly under-research. However, there are certainly indications in the literature. For instance, Chesbrough (2010) suggests that 1) barriers to BMI may be caused by underlying asset configurations, and that 2) such barriers may be overcome by constructing maps 
of present potential business models and by conferring authority within the hierarchy for experimentation to rejuvenate traditional business models.

In the following, we further develop such ideas further by a) suggesting that BMIs can be dimensionalized in terms of the complementarities they involve; b) that different kinds of BMIs create distinct managerial and organizational challenges; and c) require distinct leadership intervention and organizational design configurations to tackle these challenges successfully.

\section{Dimensionalizing and Mapping Business Model Innovations}

As already alluded to above, not all BMIs are created equal. Innovations may have a differential impact on existing complementarities (Henderson \& Clark 1990; Stieglitz \& Heine 2007) and the scope for BMI is constrained by the complementarities that are in place. For example, contrast Amazon's Kindle business model with the restructuring of Lego. In the case of Lego, many elements changed and Knudstorp changed decisively the overall Lego architecture by re-wiring many elements of the business model. In retrospect, many of the individual changes to business model elements may not have been that radical, such as making more use of outsourcing, selling off theme parks and so on. The Lego BMI may in retrospect have been more of an architectural change of numerous elements, feeding on each other. In particular, Lego did not enter new business areas (rather, they exited some).

In contrast, the Kindle eReader was a radical departure for Amazon, since it took the company into entirely new business domains. At the same time, Amazon's traditional ecommerce business was (so far) hardly affected by the new Kindle business model. The Kindle devices have been developed by lab126, a subsidiary of Amazon and a dedicated business unit that focuses on the underlying business model. 
Obviously, the system-wide, architectural changes of Lego confront business model designers with different challenges than the more modular, autonomous BMI of the Kindle. Thus, Lego and Amazon differ in terms of the breadth of changes in the business model. Modular changes to a business model are confined to particular business units or departments, while not changing elements in other parts of the firm. Architectural changes rewire complementarities across business units and departments.

Furthermore, BMIs may differ in the depth of changes (Katila \& Ahuja 2002). The Amazon Kindle offers a new value proposition - the What in the context of business modelthat represents a radical departure from the company's e-commerce activities. In contrast, LEGO did not radically alter its answers to the "what" and "who" questions: Products were not changed dramatically and the company did not go forcefully after a new customer segment.

By combining the two dimensions of BMI—the depth and the breadth of (intended) changes to an existing BMI-we propose a 2x2 matrix to classify four forms of BMI; see Figure 2.

------ Insert Figure 2 Here --------

Note that BMI is distinct from product innovations and we only invoke product names to fix ideas.

The upper right-hand corner represents the continuous refinement of an existing business model, akin to incremental process innovations. To illustrate, consider continuous BMI at Google. Google's core business model remains the Internet search engine, with a clear value proposition and an appropriation regime that offers free content and revenues from advertisement. At the same time, the business model has been honed for the last decade by evolving the underlying organizational and information architecture. In the upper left-hand, we 
locate the Kindle case, where changes are radical relative to Amazon's existing business model, but they are primarily contained in a loosely coupled business unit. Because of the organizational separation of old and new business model, we call this type ambidextrous BMI (e.g. O'Reilly \& Tushman, 2004).

Facebook's attempt to integrate and monetize mobile access to their social network is an illustrative of BMI that is incremental--the "what" and the "who" do not change substantially-while being architectural in nature, affecting the entire system of value-creating and valuecapturing activities, thereby changing fundamentally the logic of the underlying business model. Because the focus is on the gradual transformation of the BM we refer to it as evolutionary BMI. Finally, Steve Jobs' radical restructuring of Apple is a primary example for a revolutionary BMI that is both radical and architectural. The new business model - creating a device-independent eco-system - required new hardware devices, integrated software development of operating systems, a different approach to application software, and new retail structures.

Amazon has launched multiple versions of Kindle device - and these product innovations follow the logic of the business model. In fact, BMI often precedes product innovation by spelling out the logic of value creation and value appropriation and thereby providing the organizational architecture for product development.

\section{LEADING AND DESIGNING COMPANIES FOR BUSINESS MODEL INNOVATION Challenges of Business Model Innovations}

Because of the complementarities among elements of a business model, innovating existing business models present unique challenges whose severity depends on the form of the BMI that the company seeks to implement (cf. Figure 2). In particular, the complementarity framework directs attention to three challenges: First, inertial forces caused by the existing set of 
complementary elements in the traditional business model; second, the limits to ex ante planning; and, third, the problem of maintaining coherence among business model elements.

The first challenge relates to the inertia caused by the system of existing elements of a business model. Given that the existing logic may have gradually emerged over long stretches of time, the present model typically offers a tight fit of elements and a compelling logic, especially if it made the firm successful in the past. Incremental interventions, that is, changing just a few elements, might improve upon the status quo, but they will not radically alter the existing business model (Milgrom \& Roberts, 1990). Moreover, isolated and uncoordinated changes often fail to improve performance; the new initiative does not fit to the existing business model and will therefore be discarded (Siggelkow \& Rivkin, 2003). That is, the system is set up for the incremental and modular improvement of the existing business model (continuous BMI in Figure 2), but other forms of BMI are much harder to initiate and sustain successfully due to the conservative pull of the existing complementarities

The second challenge is caused by the complexity of complementary elements. Due to the inherent complexity when there are many interacting elements, it is not easy to forecast the true performance implications of internal changes (Rivkin, 2000). For example, in the Lego case it was obvious that the turn "back to the brick" would lead to cost savings, for example, because of reduced coordination costs and diseconomies of scope, but the impact of trimming the product portfolio firm boundaries, product development, and user involvement were much harder to discern ex ante. The problem of estimating performance implications becomes more difficult when changes are architectural and more radical. Architectural changes affect many complementary elements at the same time. More radical changes imply a sharper departure from the current knowledge about the business model and take the designer into new, yet unexplored 
territory (Levinthal \& March 1993). The problem is magnified by uncertainty about market conditions. That is, the internal uncertainty about the "How" is magnified by uncertainties about the value creation ("what"), the relevant customer segment "who", and the competitive dynamics (the "How much")., When Amazon launched the Kindle, the market for eReaders and tablet PCs was just in its formative stages. The overall implication is that Knightian uncertainty (Foss \& Klein 2012) — pervasive uncertainty about probabilities and outcomes — often challenges BMI, especially of the revolutionary BMI in Figure 2.

Finally, the third challenge relates to the requirement of establishing and maintaining coherence among business model elements. The major insight emerging from a complementarity perspective is that individual elements have to fit to each other to realize their full potential (Milgrom \& Roberts 1990). Establishing coherence requires search and learning about how elements complements (or substitutes for) each other, while maintaining coherence calls for stabilizing and integrating the relationship between elements. This presents a clear tension to the business model designer because she needs to balance the conflicting demands of search and coordination. Otherwise, the company runs the risk of performance-damaging over-exploration (Siggelkow \& Rivkin, 2006) that might entrap the company (March, 1991), explorative search reducing performance, in turn triggering more exploration and failure in a destructive cycle. For example, the failing social network site MySpace undertook several unsuccessful business model redesigns during the last years to stay viable and prevent bankruptcy.

In sum, the challenges stemming from complementary elements in a business model become more severe with increasing depth and breadth. Increasing depth of changes invalidates prior knowledge about the underlying system of complementary elements and thereby puts a premium on search and learning. Increasing the breadth of changes disrupts coherence to a larger 
extent and coordinated action becomes critical for BMI. In the next steps, we address how leadership and organization design may be aligned with the BMI to address these outlined challenges.

\section{Leading Business Model Innovations}

Because the types of BMI differ in associated challenges, the role of top management in leading the BMI process correspondingly differs (Figure 3).

\section{------- Insert Figure 3 Here --------}

Top management as monitor. When BMI is modular and incremental, that is, it is basically a refinement of an existing business model, most development activities can be decentralized to subordinates. The organization supports the execution of the current business model while providing for its continuous improvement. Interfaces are largely standardized, with the set of complementary relationship firmly in place and offering routine integration across departments. Mutual adjustment therefore is kept to a minimum, while the primary role of incentives is to motivate optimal effort in executing the tasks inherent in the current business model.

Partial inertia here is value-enhancing, because it preserves the core of business model, and that is also the strategic intent of the BMI. The idea is to continuously improve value creation and value appropriation, although without questioning the existing answers to the What, Who, How, and How much questions. Top management's primary function is to act as the central monitor, without active involvement in the daily development of the business model. The monitoring role is to ensure that employees do not overstep their mandates and that changes to the BM do not go against its core logic. Put differently, employees tasked with business model development exercise derived judgment (Foss \& Klein, 2012). On the level of incentives, top- 
management must ensure that improvements to the current business are properly incentivized and rewarded through the design of KPIs and performance measurement systems.

Of course, this type of BMI runs the risk of being replaced by disruptive changes in the market environment. For example, Nokia engaged in largely modular and incremental improvement of their business-model in the late 2000s, assuming wrongly that the smartphone era were just an evolution of feature phones (where Nokia ruled supreme). This point to the second dimension of top management as a monitor: It is top management's responsibility to track external environments and make judgment calls whether the existing business model remains viable. Another implication is that this BMI form is ill-suited to address disruptive changes that threaten the viability of the traditional business model or to get the company out of a crisis. For example, Lego’s turnaround was only possible by a major, architectural BMI.

Top management as sponsor. In the case of a modular, radical BMI the top management team needs to act as the sponsor for the business unit (Smith \& Tushman 2005). Separation of new and old business model will often be key, it can be achieved by what prior literature has termed structural ambidexterity (O'Reilly \& Tushman 2004): Old and new business units are separated organizational as far as necessary, with linkages either regulated through standardized or by infrequent mutual adjustments sponsored by top management. The idea here is to provide for a loose coupling, so that the new unit can effectively experiment and concentrate on a radical new organization design. This is especially relevant in terms of reward structures that need to ingrain milestones and growth targets rather than productivity and profits. For example, the Kindle initiative at Amazon requires different KPIs than managers charged with the Amazon's ecommerce services. 
Strategic and tactical decision-making is largely delegated to the new unit that may concentrate fully on the new business model, without having to integrate it with the existing BM logic in other parts of the organization. For instance, most BM decisions for the Amazon Kindle were taken by Gregg Zahr, the president of Amazon's subsidiary lab126. lab126 has a different vision statement than Amazon. While Amazon's projects its vision to become the "Earth's most customer-centric company for four primary customer sets: consumers, sellers, enterprises, and content creators", ${ }^{3}$ lab126 focuses more narrowly on the seamless provision of digital content: "to make available in less than 60 seconds every book, ever written, in any language, in print our out of print; and bring the same ease-of-use, deep integration and superior selection of content to movies, TV shows, music, magazines, apps, games, and more." ${ }^{4}$ The conservative pull of the existing business model therefore is not much of a challenge, precisely because old and new initiatives are largely separated. The key task is search and experimentation — and a decentralized leadership style supports this.

Yet, the hands-off approach to this BMI form still places unique responsibilities on the top management team. First, radical BM innovations are more exploratory, implying more uncertain and distant rewards (March, 1991). The radical nature implies a higher degree of uncertainty, thereby calling for different performance metrics and KPIs that are currently in place for the established business unit. In terms of leadership challenges this has primarily an impact on the performance dimensions long which resources are allocated (Noda \& Bower 1996). Senior management has to act as an active sponsor of the new initiative, especially against internal pressures for capital re-allocations. Second, while largely modular in nature, relevant complementarities with the rest of the organization often still exist. For example, a critical

\footnotetext{
${ }^{3}$ http://phx.corporate-ir.net/phoenix.zhtml?c=97664\&p=irol-faq_pf\#14296 (February 10, 2014).

${ }^{4}$ http://www.lab126.com/our-vision.htm (February 10, 2014).
} 
element of the Kindle BM is to develop the Amazon marketplace into a platform for digital products. That obviously requires coordination choices about how integrate digital products into the marketplace, how to communicate with Kindle users, etc. To provide for coherence, the top management team must act as residual boundary spanner between the old and the new business model. A critical task in that regard is to overcome inertia in the traditional business model as the conservative pull there is especially strong. If top management refuses to get involved as a sponsor, this form of BMI often ultimately fails, because it is unable to leverage firm-wide capabilities and competitive advantages (Smith \& Tushman, 2005; Carmeli \& Halevi, 2009).

Top management as moderator. Compared to the two BMI forms discussed so far, the architectural and incremental changes in an evolutionary BMI put more demands on top management leadership. The innovation affects the entire business model and changes are not neatly confined to a separate business unit. Top management here as to act as the moderator that a) provides a coarse roadmap of system-wide interventions to innate and guide search and b) moderates the many conflicts and changes to re-establish coherence. The two roles of the moderator address the outlined challenges for BMIs.

A roadmap of system-wide interventions is required to shake up the existing set of complementarities, to trigger a broad search for a new business model, and to guide its evolution (Lovas \& Ghosal, 2000). The roadmap also signals the commitment of senior management to BMI, an important behavioral component given that a tolerance for failure is an important part for enabling search and experimentation (Levinthal \& March 1993). At the same time, the roadmap also gives purpose and direction to the search process, preventing mission creep and too much experimentation. Prior theoretical work on organizational search demonstrated that decentralization of search may result in performance-decreasing over-exploration (Siggelkow \& 
Rivkin, 2006). For example, Facebook's successful evolution toward mobile advertisement was engineered by top management, because it required many changes to core parts of its business model.

The other role of the top management moderator is to establish and maintain coherence among business elements. That requires the resolution of conflicts among business units, task that often needs centralized intervention (Williamson, 1991). For example, at LEGO, conflicts between the design studio and manufacturing emerged: While the reduction of standard LEGO bricks offered economies of scale and reduced production costs, it constraints designers in the development of new construction sets. Only after that conflict was resolved in favor of manufacturing did LEGO realize that the reduction of the designers' toolbox also facilitate user involvement in the product development process.

The broad picture here is what operations researchers have called a simulated annealing process (Carley \& Svoboda 1996): The initial heating up of search to unfreeze a system and, in turn, the gradual cooling down of search intensity. Critically, simulated annealing does not happen naturally in organizations, but demands to be carefully managed. Top management must provide the initial heat-up and the subsequent cooling-down by establishing what works and what does not work and then readjusting search away from elements that proved to be valueenhancing.

. Because the organization can rely less on standardized interfaces in the BMI process, the organization design must support mutual adjustment by providing for formal and informal arenas for communication and coordination. It is important that the reward structures are realigned with the new BM roadmap. The reward system is a primary instrument to communicate the roadmap and to motivate the development of the new BM (Siggelkow \& 
Rivkin 2003; Kaplan \& Henderson 2005). The incentive system therefore becomes an important complement to the leadership approach of the design team: Senior management may only fruitfully act as a the moderator if the criteria for moderation are clear, and one way is to communicate clearly what it expected from subordinates and employees.

Top management as architect. The revolutionary BMI—-that is, architectural and radical changes - is the most challenging and risky one. It takes the firm into new territory and is associated with a high level of Knightian uncertainty. It requires entrepreneurial judgment by the top management team, - and its communication to the entire organization. Top management becomes the architect that not just provides a broad roadmap, but who is actively involved in everyday experimentation and decision-making to realize the perceived potential of her original entrepreneurial judgment. Steve Jobs' leadership at Apple exemplifies this leadership style (Isaacson, 2011). He was obsessed with technical and business details. This also implies that many decisions are taken centrally and are not delegated to subordinates, because their derived judgment may not be aligned with the original conception of the new business model (Foss \& Klein, 2012).

Architectural, radical BMI by its very nature limits the value of standardized interfaces, but also of decentralized mutual adjustment. At the same time, incentives may only offer limited guidance, because the Knightian uncertainty inherited in the type of BMI defeats the goal of specifying and incentivizing relevant performance metrics. Indeed, the risk here is that incentives privilege easy-to-measure tasks over hard-to-measure tasks and thereby drives out search, experimentation, cooperation, and communication (e.g. Roberts, 2010). These tasks are of critical importance to address the outlined challenges of experimentation and coherence in revolutionary BMI. 


\section{CONCLUSIONS}

In this chapter, we have outlined a contingency theory of BMI. Our starting point is that to make progress regarding the understanding of the leadership and other organizational challenges of BMI, it is necessary to dimensionalize the unit of analysis. Drawing on innovation theory (Henderson \& Clark, 1990) and work on complementarities (Milgrom \& Roberts, 1990; Brynjolfsson \& Milgrom, 2013), we suggest that BMI differ in terms of the strength of the complementarities between the elements of the business model that are being innovated. Some BMI are more modular, while others are more architectural. Also, BMI can be dimensionalized in terms how radical they are. We argued that the leadership challenges systematically depend on the nature of the relevant BMI, and suggested, but did not systematically unfold, that organizational design requirements similarly systematically vary with the nature of the BMI.

While the framework we have sketched is in principle a self-contained, testable contingency theory, it is also clear that it can be extended and refined in many ways. For example, although we have directed attention to internal organization as an important aspect of how top-management can support BMI, we have not touched on the broader organizational design issues that involve the boundaries of the firm. It is clear, however, that firm boundaries must inherently be part of business model design and therefore also BMI; after all, business models involve backstream and upstream vertical linkages that transcend the boundaries of the firm. Ultimately, activities, assets and transactions are internalized within the boundaries of the firm because this affords control and authority (Hart, 1995). When activities, etc. are placed outside of the boundaries of the firm, the level of control is smaller. For example, Lego outsourced many of its plastic operations to Flextronics, a major international supply chains solutions company, but had to realize that this diminished Lego's control over plastic quality to 
an extent that Lego was not willing to accept. As a result, a number of initial outsourcing decisions were later reversed (Foss et al., 2012). In terms of the theory we have presented in this chapter, the import of the point about the boundaries of the firm is that these somehow need to be controlled for in empirical work on BMI.

Another omission is that we have neglected key process aspects of BMI. Thus, we have not addressed issues of managerial cognition related to sensing the need for BMI. It is also intuitive that dynamics in the top-management team can influence the success of business model, depending on the nature of the BMI. Thus, architectural BMI, particularly when these are also radical (cf. Figure 2) require an effective, aligned top-management team. It may also require a relatively large top-management team with many functional specialists in order to secure that the team is close to those operations and processes that not only need to be changed but also need to have those changes tightly coordinated. Future work will, to borrow a phrase, address these issues. 


\section{REFERENCES}

Amit, R. \& Zott, C. 2012. Creating value through business model innovation. MIT Sloan Management Review, 53: 41-49.

Bellman, R. and Clark,C. (1957). On the Construction of a Multi-Stage, Multi-Person Business Game. Operations Research, 5(4): 469- 503.

Brynjolfsson, E. \& Milgrom, M. 2013. Complementarity in organizations. In Gibbons, R. \& Roberts, J., eds. Handbook of Organizational Economics. Princeton: Princeton University Press.

Brynjolfsson, E., Renshaw, A., \& Van Alstyne, M. (1997). The matrix of change. MIT Sloan Management Review, 38: 37-54.

Carley, K. M., \& Svoboda, D. M. (1996). Modeling organizational adaptation as a simulated annealing process. Sociological Methods \& Research, 25(1), 138-168.

Carmeli, A., \& Halevi, M. Y. (2009). How top management team behavioral integration and behavioral complexity enable organizational ambidexterity: The moderating role of contextual ambidexterity. The Leadership Quarterly, 20(2), 207-218.

Casadesus-Masanell, R., and JE. Ricart. (2010). From strategy to business models and onto tactics. Long Range Planning, 43, 195-215.

Chesbrough, H. W. (2007). Business model innovation: It's not just about technology anymore. Strategy and Leadership, 35: 12-17.

Chesbrough, H. W. (2010). Business model innovation: opportunities and barriers. Long Range Planning, 43(2), 354-363.

Chesbrough, H.W. \& RS. Rosenbloom. (2002). The role of the business model in capturing value from innovation: Evidence from Xerox Corporation's technology spin-off companies. Industrial and Corporate Change, 11(3), 529-555.

Demil B., \& S. Lecocq. (2010). Business model evolution: in search of dynamic consistency. Long Range Planning, 43: 227-246.

Doz, Y. and Kosenen, M. (2010). Embedding strategic agility: A leadership agenda for accelerating business model renewal. Long Range Planning, 43: 370-382.

Foss, N. J., \& Klein, P. G. (2012). Organizing entrepreneurial judgment: A new approach to the firm. Cambridge University Press. 
Foss, N.J., Schultz, M., Pedersen, T., \& Pyndt, J. (2012). Management Innovation. Cambridge: Cambridge University Press.

Gavetti, G., \& Levinthal, D. (2000). Looking forward and looking backward: Cognitive and experiential search. Administrative Science Quarterly, 45(1), 113-137.

Gavetti, G., \& Rivkin, J. W. (2007). On the origin of strategy: Action and cognition over time. Organization Science, 18(3), 420-439.

Hart, O. (1995). Firms, Contracts, and Financial Structure. Oxford: The Clarendon Press.

Henderson, R. M., \& Clark, K. B. (1990). Architectural innovation: the reconfiguration of existing product technologies and the failure of established firms. Administrative Science Quarterly, 9-30.

Isaacson, W. (2011). Steve Jobs. New York: Simon \& Schuster.

Jones, G. M. (1960). Educators, Electrons, and Business Models. Accounting Review 35(4): 619-626.

Kaplan, S., \& Henderson, R. (2005). Inertia and incentives: Bridging organizational economics and organizational theory. Organization Science, 16(5), 509-521.

Katila, R., \& Ahuja, G. (2002). Something old, something new: A longitudinal study of search behavior and new product introduction. Academy of management journal, 45(6), 11831194.

Kauffman, S. (1993). The origins of order: Self organization and selection in evolution. Oxford University Press.

Lenox, M. J., Rockart, S. F., \& Lewin, A. Y. (2010). Does interdependency affect firm and industry profitability? An empirical test. Strategic Management Journal, 31(2), 121-139.

Levinthal, D. A. (1997). Adaptation on rugged landscapes. Management science, 43(7), 934-950.

Levinthal, D. A., \& March, J. G. (1993). The myopia of learning. Strategic Management Journal, 14(S2), 95-112.

Lovas, B., \& Ghoshal, S. (2000). Strategy as guided evolution. Strategic Management Journal, 21(9), 875-896.

March, J. G. (1991). Exploration and exploitation in organizational learning. Organization science, 2(1), 71-87.

Margretta, J. (2002). Why Business Models Matter. Harvard Business Review, 80 (5), 86-92. 
Massa, L. \& Tucci, C.L. (2013). Business model innovation. Forthcoming in Oxford Handbook of Innovation Management. Oxford: Oxford University Press.

Milgrom, P., \& Roberts, J. (1990). The economics of modern manufacturing: Technology, strategy, and organization. The American Economic Review, 511-528.

Mintzberg, H., \& Waters, J. A. (1985). Of strategies, deliberate and emergent. Strategic Management Journal, 6(3), 257-272.

Noda, T., \& Bower, J. L. (1996). Strategy making as iterated processes of resource allocation. Strategic Management Journal, 17(S1), 159-192.

O’Reilly, C. A., \& Tushman, M. L. (2004). The ambidextrous organization. Harvard Business Review, 82(4), 74-83.

Rivkin, J. W., \& Siggelkow, N. (2003). Balancing search and stability: Interdependencies among elements of organizational design. Management Science, 49(3), 290-311.

Siggelkow, N. (2002). Misperceiving interactions among complements and substitutes: Organizational consequences. Management Science, 48(7), 900-916.

Siggelkow, N., \& Rivkin, J. W. (2006). When exploration backfires: Unintended consequences of multilevel organizational search. Academy of Management Journal, 49(4), 779-795.

Rivkin, J. W. (2000). Imitation of complex strategies. Management Science, 46(6), 824-844.

Roberts, J. (2010). Designing incentives in organizations. Journal of institutional economics, 6(1), 125-132.

Rumelt, R. P. (1984). Toward a strategic theory of the firm. In R. Lamb (ed.), Competitive Strategic Management, Prentice Hall, Englewood Cliffs, NJ, pp. 550-570.

Rumelt, R.P., Schendel, D. \& Teece, D.J. 1991. Strategic management and economics. Strategic management Journal, 12: 5-29.

Ryall, M. D. (2009). Causal ambiguity as a source of sustained capability-based advantages. Management Science, 55(3), 389-403.

Simon, H.A. (1969). The sciences of the artificial. Harvard, MA: MIT Press.

Smith, W. K., \& Tushman, M. L. (2005). Managing strategic contradictions: A top management model for managing innovation streams. Organization Science, 16(5), 522-536.

Stieglitz, N., \& Heine, K. (2007). Innovations and the role of complementarities in a strategic theory of the firm. Strategic Management Journal, 28(1), 1-15. 
Teece, D. J. (1986). Profiting from innovation: Implications for integration, collaboration, licensing and public policy. Research Policy, 15: 285-305.

Teece, D. J. (2010). Business models, business strategy and innovation. Long Range Planning, 43, 172-194.

Williamson, O. E. (1991). Comparative economic organization: The analysis of discrete structural alternatives. Administrative Science Quarterly, 269-296.

Zott, C., and R. Amit. (2010). Business model design: an activity system perspective. Long Range Planning, 43, 216-226.

Zott, C., R. Amit and L. Massa. (2011). The business model: Recent developments and future research. Journal of Management, 37: 1019-1042, 
Figure 1: Mapping Complementarities in the Lego Business Model Innovation

\begin{tabular}{|c|l|l|l|l|}
\hline & What? & \multicolumn{1}{|c|}{ Who? } & \multicolumn{1}{c|}{ How? } & \multicolumn{1}{c|}{ How Much? } \\
\hline What? & & $\begin{array}{l}\text { "Back to basic" } \\
\rightarrow \Delta \text { segments. }\end{array}$ & $\begin{array}{l}\text { Construction } \\
\text { aspect } \\
\text { strengthened by } \\
\text { digitalization. }\end{array}$ & $\begin{array}{l}\text { Selling off theme parks, } \\
\text { etc. boosted revenue and } \\
\text { cut cost }\end{array}$ \\
\hline Who? & & & $\begin{array}{l}\text { New segments } \\
\text { can be reached } \\
\text { through } \\
\text { digitalization }\end{array}$ & $\begin{array}{l}\text { New profitable segments } \\
\text { were reached. }\end{array}$ \\
\hline How? & & & $\begin{array}{l}\text { Outsourcing is a tool for } \\
\text { cost-cutting. }\end{array}$ \\
\hline How Much? & & & & \\
\hline
\end{tabular}

Figure 2: Dimensionalizing Business Model Innovation

\begin{tabular}{|l|l|l|}
\hline \multicolumn{1}{|c|}{ Depth of BM changes } & \multicolumn{1}{c|}{ Incremental } & \multicolumn{1}{c|}{ Radical } \\
Breadth of BM changes & $\begin{array}{l}\text { (I) Continuous BMI. Example: } \\
\text { Google's search engine }\end{array}$ & $\begin{array}{l}\text { (II) Ambidextrous } \\
\text { BMI. Example: } \\
\text { Amazon's Kindle }\end{array}$ \\
\hline Modular & (III) Evolutionary BMI. \\
& Example: Mobile Facebook & $\begin{array}{l}\text { (IV) Revolutionary } \\
\text { BMI. Example: } \\
\text { Apple's iModel }\end{array}$ \\
\hline Architectural
\end{tabular}


Figure 3: The Role of Top Management Different Business Model Innovations

\begin{tabular}{|c|c|c|}
\hline $\begin{array}{l}\text { Depth of BM changes } \\
\text { Breadth of BM changes }\end{array}$ & Incremental & Radical \\
\hline Modular & $\begin{array}{l}\text { TM as monitor } \\
\text { Decentralization - } \\
\text { very limited role for top } \\
\text { management intervention }\end{array}$ & $\begin{array}{l}\text { TM as sponsor } \\
\text { Decentralization - but } \\
\text { sponsor in top } \\
\text { management team } \\
\text { Top management pays } \\
\text { attention to } \\
\text { organizational } \\
\text { externalities }\end{array}$ \\
\hline Architectural & $\begin{array}{l}\text { TM as moderator } \\
\text { Strategic intent }- \text { top } \\
\text { management provides } \\
\text { roadmap and active } \\
\text { participation in mutual } \\
\text { adjustment }\end{array}$ & $\begin{array}{l}\text { TM as architect } \\
\text { Active involvement - } \\
\text { in everyday decision- } \\
\text { making, attention to } \\
\text { detail, centralized } \\
\text { decisions, highly } \\
\text { aligned top } \\
\text { management team }\end{array}$ \\
\hline
\end{tabular}




\section{SMG - Working Papers \\ www.cbs.dk/smg \\ 2003}

2003-1: Nicolai J. Foss, Kenneth Husted, Snejina Michailova, and Torben Pedersen: Governing Knowledge Processes: Theoretical Foundations and Research Opportunities.

2003-2: Yves Doz, Nicolai J. Foss, Stefanie Lenway, Marjorie Lyles, Silvia Massini, Thomas P. Murtha and Torben Pedersen: Future Frontiers in International Management Research: Innovation, Knowledge Creation, and Change in Multinational Companies.

2003-3: Snejina Michailova and Kate Hutchings: The Impact of In-Groups and OutGroups on Knowledge Sharing in Russia and China CKG Working Paper.

2003-4: Nicolai J. Foss and Torben Pedersen: The MNC as a Knowledge Structure: The Roles of Knowledge Sources and Organizational Instruments in MNC Knowledge Management CKG Working Paper.

2003-5: Kirsten Foss, Nicolai J. Foss and Xosé H. Vázquez-Vicente: “Tying the Manager's Hands": How Firms Can Make Credible Commitments That Make Opportunistic Managerial Intervention Less Likely CKG Working Paper.

2003-6: Marjorie Lyles, Torben Pedersen and Bent Petersen: Knowledge Gaps: The Case of Knowledge about Foreign Entry.

2003-7: Kirsten Foss and Nicolai J. Foss: The Limits to Designed Orders: Authority under "Distributed Knowledge" CKG Working Paper.

2003-8: Jens Gammelgaard and Torben Pedersen: Internal versus External Knowledge Sourcing of Subsidiaries - An Organizational Trade-Off.

2003-9: Kate Hutchings and Snejina Michailova: Facilitating Knowledge Sharing in Russian and Chinese Subsidiaries: The Importance of Groups and Personal Networks Accepted for publication in Journal of Knowledge Management.

2003-10: Volker Mahnke, Torben Pedersen and Markus Verzin: The Impact of Knowledge Management on MNC Subsidiary Performance: the Role of Absorptive Capacity CKG Working Paper.

2003-11: Tomas Hellström and Kenneth Husted: Mapping Knowledge and Intellectual Capital in Academic Environments: A Focus Group Study Accepted for publication in Journal of Intellectual Capital CKG Working Paper.

2003-12: Nicolai J Foss: Cognition and Motivation in the Theory of the Firm: Interaction or "Never the Twain Shall Meet"? Accepted for publication in Journal des Economistes et des Etudes Humaines CKG Working Paper.

2003-13: Dana Minbaeva and Snejina Michailova: Knowledge Transfer and Expatriation Practices in MNCs: The Role of Disseminative Capacity.

2003-14: Christian Vintergaard and Kenneth Husted: Enhancing Selective Capacity Through Venture Bases. 


\section{4}

2004-1: Nicolai J. Foss: Knowledge and Organization in the Theory of the Multinational Corporation: Some Foundational Issues

2004-2: Dana B. Minbaeva: HRM Practices and MNC Knowledge Transfer

2004-3: Bo Bernhard Nielsen and Snejina Michailova: Toward a Phase-Model of Global Knowledge Management Systems in Multinational Corporations

2004-4: Kirsten Foss \& Nicolai J Foss: The Next Step in the Evolution of the RBV: Integration with Transaction Cost Economics

2004-5: Teppo Felin \& Nicolai J. Foss: Methodological Individualism and the Organizational Capabilities Approach

2004-6: Jens Gammelgaard, Kenneth Husted, Snejina Michailova: Knowledge-sharing Behavior and Post-acquisition Integration Failure

2004-7: Jens Gammelgaard: Multinational Exploration of Acquired R\&D Activities

2004-8: Christoph Dörrenbächer \& Jens Gammelgaard: Subsidiary Upgrading? Strategic Inertia in the Development of German-owned Subsidiaries in Hungary

2004-9: Kirsten Foss \& Nicolai J. Foss: Resources and Transaction Costs: How the Economics of Property Rights Furthers the Resource-based View

2004-10: Jens Gammelgaard \& Thomas Ritter: The Knowledge Retrieval Matrix: Codification and Personification as Separate Strategies

2004-11: Nicolai J. Foss \& Peter G. Klein: Entrepreneurship and the Economic Theory of the Firm: Any Gains from Trade?

2004-12: Akshey Gupta \& Snejina Michailova: Knowledge Sharing in Knowledge-Intensive Firms: Opportunities and Limitations of Knowledge Codification

2004-13: Snejina Michailova \& Kate Hutchings: Knowledge Sharing and National Culture: A Comparison Between China and Russia

\section{5}

2005-1: Keld Laursen \& Ammon Salter: My Precious - The Role of Appropriability Strategies in Shaping Innovative Performance

2005-2: Nicolai J. Foss \& Peter G. Klein: The Theory of the Firm and Its Critics: A Stocktaking and Assessment

2005-3: Lars Bo Jeppesen \& Lars Frederiksen: Why Firm-Established User Communities Work for Innovation: The Personal Attributes of Innovative Users in the Case of Computer-Controlled Music

2005-4: Dana B. Minbaeva: Negative Impact of HRM Complementarity on Knowledge Transfer in MNCs

2005-5: Kirsten Foss, Nicolai J. Foss, Peter G. Klein \& Sandra K. Klein: Austrian Capital 
Theory and the Link Between Entrepreneurship and the Theory of the Firm

2005-1: Nicolai J. Foss: The Knowledge Governance Approach

2005-2: Torben J. Andersen: Capital Structure, Environmental Dynamism, Innovation Strategy, and Strategic Risk Management

2005-3: Torben J. Andersen: A Strategic Risk Management Framework for Multinational Enterprise

2005-4: Peter Holdt Christensen: Facilitating Knowledge Sharing: A Conceptual Framework

2005-5 Kirsten Foss \& Nicolai J. Foss: Hands Off! How Organizational Design Can Make Delegation Credible

2005-6 Marjorie A. Lyles, Torben Pedersen \& Bent Petersen: Closing the Knowledge Gap in Foreign Markets - A Learning Perspective

2005-7 Christian Geisler Asmussen, Torben Pedersen \& Bent Petersen: How do we Capture "Global Specialization" when Measuring Firms' Degree of internationalization?

2005-8 Kirsten Foss \& Nicolai J. Foss: Simon on Problem-Solving: Implications for New Organizational Forms

2005-9 Birgitte Grøgaard, Carmine Gioia \& Gabriel R.G. Benito: An Empirical Investigation of the Role of Industry Factors in the Internationalization Patterns of Firms

2005-10 Torben J. Andersen: The Performance and Risk Management Implications of Multinationality: An Industry Perspective

2005-11 Nicolai J. Foss: The Scientific Progress in Strategic Management: The case of the Resource-based view

2005-12 Koen H. Heimeriks: Alliance Capability as a Mediator Between Experience and Alliance Performance: An Empirical Investigation Into the Alliance Capability Development Process

2005-13 Koen H. Heimeriks, Geert Duysters \& Wim Vanhaverbeke: Developing Alliance Capabilities: An Empirical Study

2005-14 JC Spender: Management, Rational or Creative? A Knowledge-Based Discussion

\section{6}

2006-1: Nicolai J. Foss \& Peter G. Klein: The Emergence of the Modern Theory of the Firm

2006-2: Teppo Felin \& Nicolai J. Foss: Individuals and Organizations: Thoughts on a Micro-Foundations Project for Strategic Management and Organizational Analysis

2006-3: Volker Mahnke, Torben Pedersen \& Markus Venzin: Does Knowledge Sharing 
Pay? An MNC Subsidiary Perspective on Knowledge Outflows

2006-4: Torben Pedersen: Determining Factors of Subsidiary Development

2006-5 Ibuki Ishikawa: The Source of Competitive Advantage and Entrepreneurial Judgment in the RBV: Insights from the Austrian School Perspective

2006-6 Nicolai J. Foss \& Ibuki Ishikawa: Towards a Dynamic Resource-Based View: Insights from Austrian Capital and Entrepreneurship Theory

2006-7 Kirsten Foss \& Nicolai J. Foss: Entrepreneurship, Transaction Costs, and Resource Attributes

2006-8 Kirsten Foss, Nicolai J. Foss \& Peter G. Klein: Original and Derived Judgement: An Entrepreneurial Theory of Economic Organization

2006-9 Mia Reinholt: No More Polarization, Please! Towards a More Nuanced Perspective on Motivation in Organizations

2006-10 Angelika Lindstrand, Sara Melen \& Emilia Rovira: Turning social capital into business? A study of Swedish biotech firms' international expansion

2006-11 Christian Geisler Asmussen, Torben Pedersen \& Charles Dhanaraj: Evolution of Subsidiary Competences: Extending the Diamond Network Model

2006-12 John Holt, William R. Purcell, Sidney J. Gray \& Torben Pedersen: Decision Factors Influencing MNEs Regional Headquarters Location Selection Strategies

2006-13 Peter Maskell, Torben Pedersen, Bent Petersen \& Jens Dick-Nielsen: Learning Paths to Offshore Outsourcing - From Cost Reduction to Knowledge Seeking

2006-14 Christian Geisler Asmussen: Local, Regional or Global? Quantifying MNC Geographic Scope

2006-15 Christian Bjørnskov \& Nicolai J. Foss: Economic Freedom and Entrepreneurial Activity: Some Cross-Country Evidence

2006-16 Nicolai J. Foss \& Giampaolo Garzarelli: Institutions as Knowledge Capital: Ludwig M. Lachmann's Interpretative Institutionalism

2006-17 Koen H. Heimriks \& Jeffrey J. Reuer: How to Build Alliance Capabilities

2006-18 Nicolai J. Foss, Peter G. Klein, Yasemin Y. Kor \& Joseph T. Mahoney: Entrepreneurship, Subjectivism, and the Resource - Based View: Towards a New Synthesis

2006-19 Steven Globerman \& Bo B. Nielsen: Equity Versus Non-Equity International Strategic Alliances: The Role of Host Country Governance

\section{7}

2007-1 Peter Abell, Teppo Felin \& Nicolai J. Foss: Building Micro-Foundations for the Routines, Capabilities, and Performance Links 
2007-2 Michael W. Hansen, Torben Pedersen \& Bent Petersen: MNC Strategies and Linkage Effects in Developing Countries

2007-3 Niron Hashai, Christian G. Asmussen, Gabriel R.G. Benito \& Bent Petersen: Predicting the Diversity of Foreign Entry Modes

2007-4 Peter D. Ørberg Jensen \& Torben Pedersen: Whether and What to Offshore?

2007-5 Ram Mudambi \& Torben Pedersen: Agency Theory and Resource Dependency Theory: Complementary Explanations for Subsidiary Power in Multinational Corporations

2007-6 Nicolai J. Foss: Strategic Belief Management

2007-7 Nicolai J. Foss: Theory of Science Perspectives on Strategic Management Research: Debates and a Novel View

2007-8 Dana B. Minbaeva: HRM Practices and Knowledge Transfer in MNCs

2007-9 Nicolai J. Foss: Knowledge Governance in a Dynamic Global Context: The Center for Strategic Management and Globalization at the Copenhagen Business School

2007-10 Paola Gritti \& Nicolai J. Foss: Customer Satisfaction and Competencies: An Econometric Study of an Italian Bank

2007-11 Nicolai J. Foss \& Peter G. Klein: Organizational Governance

2007-12 Torben Juul Andersen \& Bo Bernhard Nielsen: The Effective Ambidextrous Organization: A Model of Integrative Strategy Making Processes.

\section{8}

2008-1 Kirsten Foss \& Nicolai J. Foss: Managerial Authority When Knowledge is Distributed: A Knowledge Governance Perspective

2008-2 Nicolai J. Foss: Human Capital and Transaction Cost Economics.

2008-3 Nicolai J. Foss \& Peter G. Klein: Entrepreneurship and Heterogeneous Capital.

2008-4 Nicolai J. Foss \& Peter G. Klein: The Need for an Entrepreneurial Theory of the Firm.

2008-5 Nicolai J. Foss \& Peter G. Klein: Entrepreneurship: From Opportunity Discovery to Judgment.

2008-6 Mie Harder: How do Rewards and Management Styles Influence the Motivation to Share Knowledge?

2008-7 Bent Petersen, Lawrence S. Welch \& Gabriel R.G. Benito: Managing the Internalisation Process - A Theoretical Perspective.

2008-8 Torben Juul Andersen: Multinational Performance and Risk Management Effects: Capital Structure Contingencies. 
2008-9 Bo Bernard Nielsen: Strategic Fit and the Role of Contractual and Procedural Governance in Alliances: A Dynamic Perspective.

2008-10 Line Gry Knudsen \& Bo Bernhard Nielsen: Collaborative Capability in R\&D Alliances: Exploring the Link between Organizational and Individual level Factors.

2008-11 Torben Juul Andersen \& Mahesh P. Joshi: Strategic Orientations of Internationalizing Firms: A Comparative Analysis of Firms Operating in Technology Intensive and Common Goods Industries.

2008-12 Dana Minbaeva: HRM Practices Affecting Extrinsic and Intrinsic Motivation of Knowledge Receivers and their Effect on Intra-MNC Knowledge Transfer.

2008-13 Steen E. Navrbjerg \& Dana Minbaeva: HRM and IR in Multinational Corporations: Uneasy Bedfellows?

2008-14 Kirsten Foss \& Nicolai J. Foss: Hayekian Knowledge Problems in Organizational Theory.

2008-15 Torben Juul Andersen: Multinational Performance Relationships and Industry Context.

2008-16 Larissa Rabbiosi: The Impact of Subsidiary Autonomy on MNE Knowledge Transfer: Resolving the Debate.

2008-17 Line Gry Knudsen \& Bo Bernhard Nielsen: Organizational and Individual Level Antecedents of Procedural Governance in Knowledge Sharing Alliances.

2008-18 Kirsten Foss \& Nicolai J. Foss: Understanding Opportunity Discovery and Sustainable Advantage: The Role of Transaction Costs and Property Rights.

2008-19 Teppo Felin \& Nicolai J. Foss: Social Reality, The Boundaries of Self-fulfilling Prophecy, and Economics.

2008-20 Yves Dos, Nicolai J. Foss \& José Santos: A Knowledge System Approach to the Multinational Company: Conceptual Grounding and Implications for Research

2008-21 Sabina Nielsen \& Bo Bernhard Nielsen: Why do Firms Employ foreigners on Their Top Management Teams? A Multi-Level Exploration of Individual and Firm Level Antecedents

2008-22 Nicolai J. Foss: Review of Anders Christian Hansen's “Uden for hovedstrømmen - Alternative strømninger i økonomisk teori"

2008-23 Nicolai J. Foss: Knowledge, Economic Organization, and Property Rights

2008-24 Sjoerd Beugelsdijk, Torben Pedersen \& Bent Petersen: Is There a Trend Towards Global Value Chain Specialization? - An Examination of Cross Border Sales of US Foreign Affiliates 
2008-25 Vikas Kumar, Torben Pedersen \& Alessandro Zattoni: The performance of business group firms during institutional transition: A longtitudinal study of Indian firms

2008-26 Sabina Nielsen \& Bo B. Nielsen: The effects of TMT and Board Nationality Diversity and Compensation on Firm Performance

2008-27 Bo B. Nielsen \& Sabina Nielsen: International Diversification Strategy and Firm Performance: A Multi-Level Analysis of Firm and Home Country Effects

\section{9}

2009-1 Nicolai J. Foss: Alternative Research Strategies in the Knowledge Movement: From Macro Bias to Micro-Foundations and Multi-Level Explanation

2009-2 Nicolai J. Foss \& Peter G. Klein: Entrepreneurial Alertness and Opportunity Discovery: Origins, Attributes, Critique

2009-3 Nicolai J. Foss \& Dana B. Minbaeva: Governing Knowledge: The Strategic Human Resource Management Dimension

2009-4 Nils Stieglitz \& Nicolai J. Foss: Opportunities and New Business Models: Transaction Cost and Property Rights Perspectives on Entrepreneurships

2009-5 Torben Pedersen: Vestas Wind Systems A/S: Exploiting Global R\&D Synergies

2009-6 Rajshree Agarwal, Jay B. Barney, Nicolai J. Foss \& Peter G. Klein: Heterogeneous Resources and the Financial Crisis: Implications of Strategic Management Theory

2009-7 Jasper J. Hotho: A Measure of Comparative Institutional Distance

2009-8 Bo B. Nielsen \& Sabina Nielsen: The Impact of Top Management Team Nationality Diversity and International Experience on Foreign Entry Mode

2009-9 Teppo Felin \& Nicolai Juul Foss: Experience and Repetition as Antecedents of Organizational Routines and Capabilities: A Critique of Behaviorist and Empiricist Approaches

2009-10 Henk W. Volberda, Nicolai J. Foss \& Marjorie E. Lyles: Absorbing the Concept of Absorptive Capacity: How To Realize Its Potential in the Organization Field

2009-11 Jan Stentoft Arlbjørn, Brian Vejrum Wæhrens, John Johansen \& Torben Pedersen: Produktion i Danmark eller offshoring/outsourcing: Ledelsesmæssige udfordringer 


\section{0}

2010-1 Dana B. Minbaeva, Kristiina Mäkelä \& Larissa Rabbiosi: Explaining Intraorganizational Knowledge Transfer at the Individual Level

2010-2 Dana B.Minbaeva \& Torben Pedersen: Governing Individual Knowledge Sharing Behavior

2010-3 Nicolai J. Foss \& Peter G. Klein: Alertness, Judgment, and the Antecedents of Entrepreneurship

2010-4 Nicolai J.Foss \& Joseph T.Mahoney: Exploring Knowledge Governance

2010-5 Jasper J. Hotho, Florian Becker-Ritterspach \& Ayse Saka-Helmhout: Enriching Absorptive Capacity Through Social Interaction

2010-6 Nicolai J. Foss \& Bo B. Nielsen: Researching Collaborative Advantage: Some Conceptual and Multi-level Issues

2010-7 Nicolai J. Foss \& Nils Stieglitz: Modern Resource-Based Theory(ies)

2010-8 Christian Bjørnskov \& Nicolai J. Foss: Do Economic Freedom and Entrepreneurship Impact Total Factor Productivity?

2010-9 Gabriel R.G. Benito, Bent Petersen \& Lawrence S. Welch: Mode Combinations and International Operations: Theoretical Issues and an Empirical Investigation

\section{1}

2011-1 Peter D. Ørberg Jensen \& Bent Petersen: Human Asset Internalization and Global Sourcing of Services - A Strategic Management Analysis on Activity-level

2011-2 Mie Harder: Management Innovation Capabilities: A Typology and Propositions for Management Innovation Research

2011-3 Mie Harder: Internal Antecedents of Management Innovation: The effect of diagnostic capability and implementation capability 
2011-4 Mie Harder: Explaining Management Innovation Pervasiveness: The Role of Internal Antecedents

2011-5 Mie Harder: Internal Determinants of Product Innovation and Management Innovation: The Effect of Diagnostic Capability and Implementation Capability

2011-6 Nicolai J. Foss, Peter G. Klein \& Per L. Bylund: Entrepreneurship and the Economics of the Firm

2011-7 Nicolai J. Foss \& Jacob Lyngsie: The Emerging Strategic Entrepreneurship Field: Origins, Key Tenets and Research Gaps

2011-8 Nicolai J. Foss: Entrepreneurship in the Context of the Resource-based View of the Firm

2011-9 Bent Petersen, Gabriel R.G. Benito, Olesya Dovgan \& Lawrence Welch: Offshore outsourcing: A dynamic, operation mode perspective

2011-10 Bent Petersen, Gabriel R. G. Benito \& Lawrence Welch: Dynamics of Foreign Operation Modes and their Combinations: Insights for International Strategic Management

2011-11 Nicolai J. Foss: Teams, Team Motivation, and the Theory of the Firm

2011-12 Nicolai J. Foss: Knowledge Governance: Meaning, Nature, Origins, and Implications

2011-13 Nicolai J. Foss, Kirsten Foss \& Phillip C. Nell: MNC Organizational Form and Subsidiary Motivation Problems: Controlling Intervention Hazards in the Network MNC

2011-14 Kåre Moberg: Evaluating Content Dimensions in Entrepreneurship Education

\section{2}

2012-1 Nicolai J. Foss, Nicholas Argyres, Teppo Felin \& Todd Zenger: The Organizational Economics of Organizational Capability and Heterogeneity: A Research Agenda 
2012-2 Torben J. Andersen, Carina Antonia Hallin \& Sigbjørn Tveterås: A Prediction Contest: The Sensing of Frontline Employees Against Executive Expectations

2012-3 Peter G. Klein, Jay B. Barney \& Nicolai J. Foss: Strategic Entrepreneurship

2012-4 Kåre Moberg: The Impact of Entrepreneurship Education and Project-based Education on Students' Personal Development and Entrepreneurial Intentions at the Lower Levels of the Educational System: Too Much of Two Good Things?

2012-5 Keld Laursen \& Nicolai J. Foss: Human Resource Management Practices and Innovation

2012-6 Kåre Moberg: An Entrepreneurial Self-Efficacy Scale with a Neutral Wording

\section{3}

2013-1

Nicolai J. Foss, Diego Stea: The Principal's Theory of Mind: The Role of Mentalizing for Reward Design and Management in Principal-Agent Relations

2013-2 Dana Minbaeva, Chansoo Park \& Ilan Vertinsky: The Influence of Foreign Partners' Disseminative Capacities on Knowledge Transfers to International Joint Ventures

2013-3

Nicolai J. Foss \& Peter G. Klein: Hayek and Organizational Studies

2013-4 Kåre Moberg, Lene Vestergaard, Casper Jørgensen, Elisabeth Markussen \& Sose Hakverdyan: How to Assess the Development of Entrepreneurship Education at University Level - the Case of Denmark

2013-5 Nicolai J. Foss \& Siegwart Lindenberg: Micro-Foundations For Strategy: A Goal-Framing Perspective on the Drivers of Value Creation 
2013-6 Nicolai J. Foss, Jacob Lyngsie \& Shaker A. Zahra: The Role of External Knowledge Sources and Organizational Design in the Process of Opportunity Exploitation

2013-7 Stefan Linder \& Nicolai J. Foss: Agency Theory.

2013-8 Nicolai J. Foss, Peter G. Klein, Stefan Linder: Organizations and Markets

2013-9 Nicolai J. Foss: Towards an Organizational Economics of Heterogeneous Capabilities

2013- 10 Christian Geisler Asmussen \& Nicolai J. Foss: Competitive Advantage and the Existence of the MNC: Earlier Research and the Role of Frictions

\section{4}

2014-1 Nicolai J. Foss \& Kirsten Foss: COASIAN AND MODERN PROPERTY RIGHTS ECONOMICS: A CASE OF KUHNIAN LOST CONTENT

2014-2 Nicolai J. Foss \& Nils Stieglitz: BUSINESS MODEL INNOVATION: THE ROLE OF LEADERSHIP 